\author{
Loyalitas Kreativitas \\ Aldi Masyarakat Kreatif
}

P-ISSN 2722-2101, E-ISSN 2722-4201

Program Studi Ekonomi Manajemen Universitas Pamulang

Jurnal LOKABMAS Kreatif Vol.02,No.03.Nov2021Hal.24-30

Email:jurnalkreatif.manajemen@gmail.com

\title{
PELAKSANA PROGRAM PEMBINAAN PEMBERDAYAAN DAN KESEJATERAAN KELUARGA KEPADA IBU PKK KELURAHAN SAWAH BARU CIPUTAT, TANGERANG SELATAN
}

\author{
Krisnaldy, Andrianto, Amelia Putri, Panca Setia Budi, \\ Farza Maulida dan Vicki Ivansyah \\ ${ }^{1}$ Dosen Prodi Manajemen Fakultas Ekonomi Universitas Pamulang \\ 2,3,4,5,6 Mahasiswa Manajemen Universitas Pamulang
}

Email : dosen01890@unpam.ac.id, andrianto10595@gmail.com, liaa3985@gmail.com, setiabudipanca57@gmail.com, farzamaulida1998@gmail.com, ivansyah.iki22@gmail.com

\begin{abstract}
Abstrak.
Tujuan dari Pengabdian kepada Masyarakat (PKM) ini adalah untuk mengetahui Pelaksanaan Program Pembinaan, Pemberdayaan dan Kesejahteraan Keluarga Pada Ibu PKK beralamat di Jalan Cendrawasih Raya No.1 RT 004/003, Kelurahan Sawah Baru, Ciputat, Kota Tangerang Selatan.

Metode yang digunakan dalam PKM ini adalah penyuluhan kepada Ibu PKK Kelurahan Sawah Baru, Ciputat, Tangerang Selatan tentang : Pelaksanaan Program Pembinaan, Pemberdayaan dan Kesejahteraan Keluarga Pada Ibu PKK

Hasil dari pelaksanaan PKM ini, diharapkan Ibu PKK Kelurahan Sawah Baru dapat memahami secara optimal peran sebagai ibu rumah tangga yang dapat Pembinaan, Pemberdayaan dan Kesejahteraan Keluarga Pada Ibu PKK
\end{abstract}

\section{Kata kunci : pembinaan, pemberdayaan dan kesejateraan keluarga}

\section{Abstract.}

The purpose of Community Service (PKM) is to determine the Implementation of the Family Guidance, Empowerment and Welfare Program for the PKK Mother having her address at Jalan Cendrawasih Raya No.1 RT 004/003, Sawah Baru Village, Ciputat, South Tangerang City.

The method used in this PKM is counseling to PKK mothers in Sawah Baru Village, Ciputat, South Tangerang regarding: Implementation of Development, Empowerment and Family Welfare Programs in PKK Mothers

The results of the implementation of this PKM, it is hoped that the PKK Sawah Baru Village mother can optimally understand the role of a housewife who can foster family development, empowerment and family welfare in PKK mothers.

Keywords: coaching, empowerment and family welfare

\section{PENDAHULUAN}

Keputusan pemerintah untuk merevitalisasi dan mengelompokkan organisasi perempuan di bawah departemen dalam federasi mengakibatkan lahirnya Pemberdayaan dan Kesejahteraan
Keluarga (PKK), yaitu organisasi yang mewadahi perempuan yang tidak berada di bawah departemen. Organisasi ini bermula dari Pendidikan Kesejahteraan Keluarga yang berupaya melibatkan partisipasi dan merupakan program pendidikan perempuan. Selanjutnya 
Loyalitas Kreativitas

Aldi Masyarakat Kreatif
P-ISSN 2722-2101, E-ISSN 2722-4201

Program Studi Ekonomi Manajemen Universitas Pamulang

Jurnal LOKABMAS Kreatif Vol.02,No.03.Nov2021Hal.24-30

Email:jurnalkreatif.manajemen@gmail.com organisasi ini berubah menjadi Pembinaan Kesejahteraan Keluarga yang berupaya tidak hanya mendidik perempuan, melainkan membina dan membangun keluarga di bidang mental spiritul dan fisik material serta peningkatan mutu pangan, sandang, papan, kesehatan, dan lingkungan hidup. Bergulirnya reformasi dan disyahkannya GBHN 1999 oleh MPR serta adanya paradigma baru pembangunan dan semangat otonomi daerah, maka kepanjangan PKK berubah menjadi Pemberdayaan dan Kesejahteraan Keluarga, yaitu sebuah organisasi yang melibatkan partisipasi perempuan dan lakilaki dalam upaya mewujudkan keluarga sejahtera. Kesejahteraan keluarga menjadi tujuan utama PKK. Hal ini dikarenakan keluarga merupakan unit terkecil masyarakat yang akan berpengaruh besar terhadap kinerja pembangunan dalam mendukung program-program pemerintah. Dari keluarga yang sejahtera ini, maka tata kehidupan berbangsa dan bernegara akan dapat melahirkan ketentraman, keamanan, keharmonisan, dan kedamaian. Dengan demikian, kesejahteraan keluarga menjadi salah satu tolak ukur dan barometer dalam pembangunan dengan program-program pemerintah.

Organisasi PKK lah yang ikut berperan besar dalam pembangunan khususnya pemberdayaan masyarakat. Dengan berbagai peningkatan kegiatan ibu-ibu PKK baik di tingkat Kota, Kecamatan maupun Kelurahan. Kelompok PKK mendorong pembangunan dan program pemerintah Kota Bontang melalui kelompok-kelompok binaan yang mencapai 32 kelompok pada tahun 2010 dan 15 PKK aktif di Kota Bontang. Selain itu, dalam proses pembangunan tersebut terdapat pula kelompok masyarakat yang turut berpartisipasi berupa LSM yang jumlahnya mencapai 42 pada tahun 2010.

Dari observasi awal yang dilakukan peneliti, peneliti menemukan bahwa kegiatan dalam hal pembangunan masyarakat dan mendukung program pemerintah yang dilakukan oleh TP PKK sampai saat ini sudah cukup baik. TP PKK sudah melakukan berbagai kegiatan- kegiatan yang sampai pada unit terkecil masyarakat yaitupada kesejahteraan keluarga dan dalam pemberdayaan masyarakat juga sudah cukup baik. Pada Sumber Daya Manusianya pun sudah cukup baik. Tetapi, dalam kegiatan tersebut ada hal-hal yang menghambat yaitu waktu dan tenaga, fasilitas, dan pemahaman suami tentang Gerakan PKK. PKK menjadi gerakan untuk membantu dan mendukung program- program pemerintah dengan mendata beberapa aspek yang diperlukan seperti data warga, ibu hamil, bayi, dan balita, kelahiran, kematian, sampai kegiatan masyarakat. PKK juga harus menembus pemahaman agama yang kurang tepat, tentang pelarangan penggunaan alat kontrasepsi termasuk mereka harus memberikan penjelasan yang utuh tentang manfaat program KB kepada masyarakat yang ratarata berpendidikan rendah, mereka membantu korban kekerasan perempuan dalam rumah tangga dan masyarakat.

PKK consern dalam membela kaum miskin yang kelaparan dengan cara membantu ekonomi kaum perempuan. Program kerja PKK berorientaasi pada praksis, artinya PKK bergerak pada aksiaksi nyata memberdayakan dan memihak kaum perempuan. Dan lebih dari itu, PKK mempunyai andil besar dalam mensukseskan lomba desa.

Rumusan masalah kegiatan PKM ini adalah sebagai berikut :

1. Bagaimana cara Ibu PKK Kelurahan Sawah Baru Perogram Pembinaan, Pemberdayaan dan Kesejahteraan?

2. Bagaimana pemahaman Ibu PKK Kelurahan Sawah Baru tentang Pembinaan, Pemberdayaan dan Kesejahteraan?

Tujuan kegiatan PKM ini adalah sebagai berikut:

1. Untuk mengetahui secara optimal bagaimana Ibu PKK Kelurahan Sawah Baru memahami pentingnya pembinaan, pemberdayaan dan kesejateraan.

2. Untuk mengetahui secara optimal bagaimana Ibu PKK Kelurahan Sawah 
Loyalitas Kreativitas Aldi Masyarakat Kreatif
P-ISSN 2722-2101, E-ISSN 2722-4201

Program Studi Ekonomi Manajemen Universitas Pamulang

Jurnal LOKABMAS Kreatif Vol.02,No.03.Nov2021Hal.24-30

Email:jurnalkreatif.manajemen@gmail.com
Baru

memahami cara untuk penlakukan pembinaan, pemberdayaan dan kesejateraan.

\section{METODE PELAKSANAAN}

Metode kegiatan ini berupa pelatihan kepada Ibu PKK Kelurahan Sawah Baru Tangerang Selatan, Kami melakukan persiapan segala hal yang terkait dengan materi, bahan dan alat sesuai dengan tema secara baik. Hasil persiapan tersebut dimaksudkan agar materi tersampaikan dengan mudah dimengerti serta dipahami oleh Ibu PKK Kelurahan Sawah Baru, Ciputat, Tangerang Selatan. Berikut ini adalah tahapan pelatihan yang dilakukan

1. Membantu Ibu PKK dalam memahami peran sebagai Ibu Rumah Tangga.

Dalam hal ini sebagai solusinnya maka kepadaIbu PKK Kelurahan Sawah Baru, Ciputat, Tangerang Selatan, di berikan pemahaman tentang tujuan dan manfaat Manajemen Keuangan Keluarga.

\section{Realisasi Pemecahan Masalah}

Berdasarkan solusi yang diusulkan maka

target yang diharapkan sebagai berikut:

1. Ibu PKK Kelurahan Sawah Baru memahami tentang tugas dan kewajiban sebagai ibu rumah tangga dengan melakukan pembinaan, pemberdayaan kesejahteraan dalam rumah tangga.

2. Ibu PKK Kelurahan Sawah Baru memahami tentang pembinaan, pemberdayaan kesejahteraan.

3. Perangkat Kelurahan membantu untuk terus menerus mensosialisasikan Tentang Pentingnya pembinaan, pemberdayaan kesejahteraan.

\section{Khalayak Sasaran}

Peserta kegiatan : Ibu-Ibu PKK Kelurahan Sawah Baru, Ciputat, Tangerang Selatan.

\section{Tempat dan Waktu}

Tempat Kegiatan : Aula Serba Guna RT 004/003

Waktu Pelaksanaan : Hari Kamis, 18 Maret 2021 Jam 11.00-12.40 WIB

\section{Metode Kegiatan}

Metode yang digunakan dalam kegiatan Pengabdian Kepada Masyarakat (PKM) ini adalah melalui kegiatan penyuluhan kepada Ibu PKK Kelurahan Sawah Baru, tentang :

1. Pemahaman Ibu PKK terhadap pentingnya pembinaan, pemberdayaan kesejahteraan.

2. Pemahaman Ibu PKK tentang memprogarm pembinaan, pemberdayaan kesejahteraan

Adapun metode sebelum dan sesudah pelaksanaan PKM, adalah sebagai berikut :

1). Metode Pengumpulan Data

Untuk memperoleh data yang akurat yang dapat dipercaya kebenarannya dan relevan, maka pengumpulan data dilakukan dengan beberapa metode yaitu :

a. Wawancara

Merupakan proses untuk memperoleh data dengan cara melakukan pertanyaan, dalam hal ini dilakukan dengan Ibu Diana, selaku Ketua Ibu PKK.

b. Observasi

Merupakan proses pengumpulan data dengan mengadakan pengamatan langsung pada objek Pengabdian Kepada Masyarakat (PKM) untuk memperoleh data yang diperlukan, dengan melakukan survey langsung ke tempat PKM.

c. Dokumen 
Dokumen merupakan catatan peristiwa yang sudah berlalu, biasanya berbentuk tulisan, gambar, atau karya-karya monumental dari seseorang. Studi dokumen merupakan pelengkap dari penggunaan observasi dan wawancara. Dalam hal ini dilakukan dokumentasi berupa surat menyurat melakukan PKM di Jalan Cendrawasih Raya No.1 RT 004/003

2) Metode Pelaksanaan

Metode pelaksanaan kegiatan ini berupa penyuluhan kepada Ibu PKK Kelurahan Sawah Baru. Adapun tahapan yang dilakukan adalah sebagai berikut :

1. Tahap Persiapan

Tahap persiapan yang dilakukan meliputi :

a. Informasi awal, pada tahap ini didapatkan infomasi awal dari Ketua Ibu PKK, Ibu Diana, yang menginformasikan bahwa Ibu PKK Kelurahan Sawah Baru belum memahami secara optimal pentingnya pembinaan, pemberdayaan kesejahteraan.

b. Pemantapan dan penentuan lokasi dan sasaran. Setelah informasi awal maka ditentukan lokasi pelaksanaan dan sasaran peserta kegiatan penyuluhan. Dengan melakukan proses perijinan secara lisan terlebih dahulu untuk diadakan PKM di lokasi tersebut kepada Ketua RT 004/003 Kelurahan Sawah Baru Ciputat Tangerang Selatan, Bapak Yusdi Ismanto, dan setelah persetujuan ditentukan waktu pelaksanaan PKM yang akan diadakan pada tanggal 18 Maret 2021 dan bertempat di Aula Serba Guna RT 004/003 dengan jumlah peserta sebanyak 20 orang.

c. Penyusunan bahan/materi penyuluhan yang meliputi: slide presentasi (power point) dan makalah/materi untuk kegiatan penyuluhan berupa materi Pentingnya Manajemen Keluarga dengan sumber referensi dari buku-buku, jurnal maupun internet.

d. Persiapan perlengkapan penyuluhan, laptop dan LCD, spanduk kegiatan.

2. Tahap Pelaksanaan Penyuluhan

Tahap ini akan menjelasan tentang materi Pelaksanaan Program Pembinaan, Pemberdayaan dan Kesejahteraan Keluarga Pada Ibu PKK maupun Ibu Rumah Tangga di mana sessi ini menitik beratkan pada pemaparan materi mengenai pengembangan potensi Program Pembinaan, Pemberdayaan dan Kesejahteraan.

Metode tanya jawab sangat penting bagi para peserta pelatihan. Metode ini memberi kesempatan kepada peserta untuk menanyakan hal-hal yang masih kurang atau belum jelas dalam penyuluhan yang sudah disampaikan.

\section{HASIL DAN PEMBAHASAN}

Ibu PKK Kelurahan Sawah Baru dalam mengikuti penyuluhan sangat bersemangat dan antusias sehingga hasil kegiatan sangat memuaskan, disamping karena belum pernah mendapatkan materi Pelaksanaan Program Pembinaan, Pemberdayaan dan Kesejahteraan Keluarga Pada Ibu PKK secara detail dan jelas.

Dalam tanya jawab, juga peserta cukup banyak yang bertanya seputar peran koperasi dan fungsinya serta manfaat yang akan di dapat Ibu PKK, dan Ibu Rumah Tangga Lainnya.

Pada tahap akhir dilakukan pengisian angket/kuesioener mengenai pemahaman Pelaksanaan Program Pembinaan, Pemberdayaan dan Kesejahteraan Keluarga, sebagai tolak ukur hasl kegiatan PKM ini bisa bermanfaat untuk ibu rumah tangga lainnya. 
Loyalitas Kreativitas

Aldi Masyarakat Kreatif
P-ISSN 2722-2101, E-ISSN 2722-4201

Program Studi Ekonomi Manajemen Universitas Pamulang

Jurnal LOKABMAS Kreatif Vol.02,No.03.Nov2021Hal.24-30

Email:jurnalkreatif.manajemen@gmail.com

\subsection{Pembahasan}

\section{Hari, Kamis 18 Maret 2021}

Kegiatan intinya berupa penyuluhan dengan penyampaian materi tentang pentingnya manajemen keuangan keluarga krpada Ibu PKK Kelurahan Sawah Baru, bertujuan untuk mengetahui secara optimal bagaimana Ibu PKK berperan sebagai ibu rumah tangga, selanjutnya dilakukan tahap diskusi dan tanya jawab. Penyampaian materi diberikan oleh tim PKM.

\section{KESIMPULAN DAN SARAN}

\section{Kesimpulan}

Dengan diadakannya kegiatan PKM ini dapat diambil kesimpulan sebagai berikut :

1. Ibu PKK Kelurahan Sawah Baru Ciputat

Tangerang Selatan belum semuanya memahami secara optimal Pelaksanaan Program Pembinaan, Pemberdayaan dan Kesejahteraan Keluarga dikarenakan masih kurangnya sosialisasi Pelaksanaan Program Pembinaan, Pemberdayaan dan Kesejahteraan secara meluas.

2. Ibu PKK Kelurahan Sawah Baru belum semuanya memanfaatkan secara optimal Pelaksanaan Program Pembinaan, Pemberdayaan dan Kesejahteraan Keluarg.

\section{Saran}

1. Perlu adanya sosialisasi kepada Ibu Rumah Tangga Kelurahan Sawah Baru secara terus menerus dengan mengadakan pertemuan-pertemuan rutin.

2. Perlu dukungan baik dari pengurus Kelurahan Sawah Baru yang sudah ada/berjalan dan Ibu PKK untuk mengajak masyarakat berpartispasi.

\section{DAFTAR PUSTAKA}

Astuti, W., Purwoko, G. D., Senen, S., Sudarso, E., \& Thaharuddin, T. (2021).
MEMPERKUAT MOTIVASI BELAJAR DAN PERENCANAAN KARIER DI KELURAHAN PONDOK BENDA. Jurnal ABDIMAS Tri Dharma Manajemen, 2(1), 103-111.

Direktorat Jenderal Pemberdayaan Masyarakat dan Desa (PMD)

Departemen Dalam Negeri. 2010. Hasil Rapat Kerja Nasional VII

Elburdah, R. P., Pasaribu, V. L. D., Rahayu, S., Septiani, F., \& Metarini, R. R. A. (2021). MOMPRENEUR PENOPANG PEREKONOMIAN KELUARGA DI MASA PANDEMI COVID-19 DENGAN BISNIS ONLINE PADA KELURAHAN PONDOK BENDA. Abdi Laksana: Jurnal Pengabdian Kepada Masyarakat, 2(1), 75-82.

Pasaribu, V. L. D., Agrasadya, A., Shabrina, N., \& Krisnaldy, K. (2020). Menjadi Enterpreneur Muda Yang Memiliki Jiwa Leadership Untuk Menghadapi Masa Depan. Abdi Laksana: Jurnal Pengabdian Kepada Masyarakat, 1(1).

Pasaribu, V. L. D., Susanti, F., \& Hartuti, E. T. K. (2019). Memotivasi Siswa dan Siswi SMK Letris Indonesia di Dalam Menentukan Pilihan Untuk Melanjutkan Pendidikan Atau Bekerja Setelah Lulus Sekolah. Jurnal Pengabdian Dharma Laksana, 1(2), 161-172.

Pasaribu, V. L. D., Sulaiman, S., Sutiman, S., Thaharudin, T., \& Purnomo, B. Y. (2020). Pengenalan Letak Posyandu Terdekat Dikelurahan Pisangan Dengan Manajemen Pemasaran Revolusi 4.0 Untuk Meningkatkan Pengetahuan Masyarakat Letak Dan Fungsi Posyandu Terdekat Pada Kelurahan Pisangan. Dedikasi Pkm, l(1), 105110. 


\section{Loyalitas Kreativitas \\ Aldi Masyarakat Kreatif}

P-ISSN 2722-2101, E-ISSN 2722-4201

Program Studi Ekonomi Manajemen Universitas Pamulang Jurnal LOKABMAS Kreatif Vol.02,No.03.Nov2021Hal.24-30

Email:jurnalkreatif.manajemen@gmail.com
Pasaribu, V. L. D., Oktrima, B., Prabowo, B., Arianto, N., \& Haryoko, U. B. (2020). Progam Pendampingan Dan Penyelenggaraan Pendidikan Anak Pada Usia Dini Terhadap Prestasi Belajar Dilingkungan Rt $020 \mathrm{Rw}$ 009. Kel Giri Peni. Kec Wates. Yogyakarta. Jurnal Lokabmas Kreatif, 1(1), 71-75.

Pasaribu, V. L. D., Jannah, M., Fazar, M., Putra, S. P., Monalisa, M., \& Sofa, M. (2021). MENINGKATKAN PRODUKTIVITAS USAHA DIMASA PANDEMI PADA IBU PKK RT 004/003 KELURAHAN SAWAH BARU CIPUTAT, TANGERANG SELATAN. Abdi Laksana: Jurnal Pengabdian Kepada Masyarakat,2(2), 295301.

Pasaribu, V. L. D., Yuniati, H. L., Pranata, R., Sembayu, R., Purba, S. M., \& Nurbayani, T. T. A. (2021). MANAJEMEN KEUANGAN UNTUK MENGHADAPI DAN BERTAHAN DI ERA COVID 19. Jurnal Abdimas Tri Dharma Manajemen, 2(2), 12-18.

Pasaribu, V. L. D., Dwiyatni, A., Sabina, C., Ridwan, M., Gunawan, D. D., \& Noviani, B. C. (2021). EVALUASI PENERAPAN 3M DIMASA PANDEMIC COVID 19. Jurnal Abdimas Tri Dharma Manajemen, 2(2), 54-60.

Pasaribu, V. L. D., Syafei, A. N., Farhan, A., Aufaizah, A., Irani, C., \& Firtiayani, S. R. (2021). PENGARUH DISPLIN PROTOKOL KESEHATAN TERHADAP PENCEGAHAN PENULARAN VIRUS COVID19. Jurnal Abdimas Tri Dharma Manajemen, 2(2), 91-98.

Pasaribu, V. L. D., Septiani, F., Rahayu, S., Lismiatun, L., Arief, M., Juanda, A., ... \& Rahim, R. (2021). Forecast Analysis of Gross Regional Domestic Product based on the
Linear Regression Algorithm Technique.

Pasaribu, V. L. D., Priadi, A., Anismadiyah, V., Rahayu, S., \& Maduningtias, L. (2021). PENYULUHAN KREATIF DAN INOVATIF MENINGKATKAN MUTU PRODUKSI UMKM DI DESA BELEGA KABUPATEN GIANYAR. Pro Bono Jurnal Pengabdian Kepada Masyarakat, 1(02).

Pasaribu, V. L. D. (2021). PELATIHAN BERBASIS ONLINE DI ERA COVID-19. Jurnal Abdimas Tri Dharma Manajemen, 2(3), 26-32.

Pasaribu, V. L. D., \& Setyowati, R. (2021). ADAPTASI KEHIDUPAN NEW NORMAL PADA MASA PANDEMI COVID-19 DIYAYASAN PONDOK PESANTREN DAN PANTI ASUHAN NURUL IKHSAN KECAMATAN SETU, KOTA TANGERANG SELATAN. Jurnal Lokabmas Kreatif: Loyalitas Kreatifitas Abdi Masyarakat Kreatif, 2(2), 82-88.

Priadi, A., Pasaribu, V. L. D., Virby, S., Sairin, S., \& Wardani, W. G. (2020). Penguatan Ekonomi Kreatif Berbasis Sumber Daya Desa Dikelurahan Rempoa. Abdi Laksana: Jurnal Pengabdian Kepada Masyarakat, 1(3), 356-35

PKK. Jakarta: Penerbit Tim Penggerak PKK Pusat

James L, Gibson dkk. 1985. Organisasi. Jakarta: Penerbit Erlangga

Miles, Mathew. B dan A. Micheal Huberman, 2007. Analisis Data Kualitatif.

Senen, S., Krisnaldy, K., \& Ishak, G. (2021). PENGARUH GAYA KEPEMIMPINAN TERHADAP MOTIVASI (Studi Kasus Yayasan Nurul Ihsan). Jurnal Arastirma, 1(1). 


\section{Loyalitas Kreativitas \\ Aldi Masyarakat Kreatif}

P-ISSN 2722-2101, E-ISSN 2722-4201

Program Studi Ekonomi Manajemen Universitas Pamulang

Jurnal LOKABMAS Kreatif Vol.02,No.03.Nov2021Hal.24-30

Email:jurnalkreatif.manajemen@gmail.com

Soepandi, A., Krisnaldy, K., Purnomo, S., Senen, S., \& Syukri, A. (2020). PELATIHAN

KEWIRAUSAHAAN DAN UKM BARU PADA IBU-IBU PKK KELURAHAN BINTARO JAKARTA SELATAN. JURNAL LOKABMAS KREATIF, l(1), 100106.

\section{LAMPIRAN : FOTO KEGIATAN}
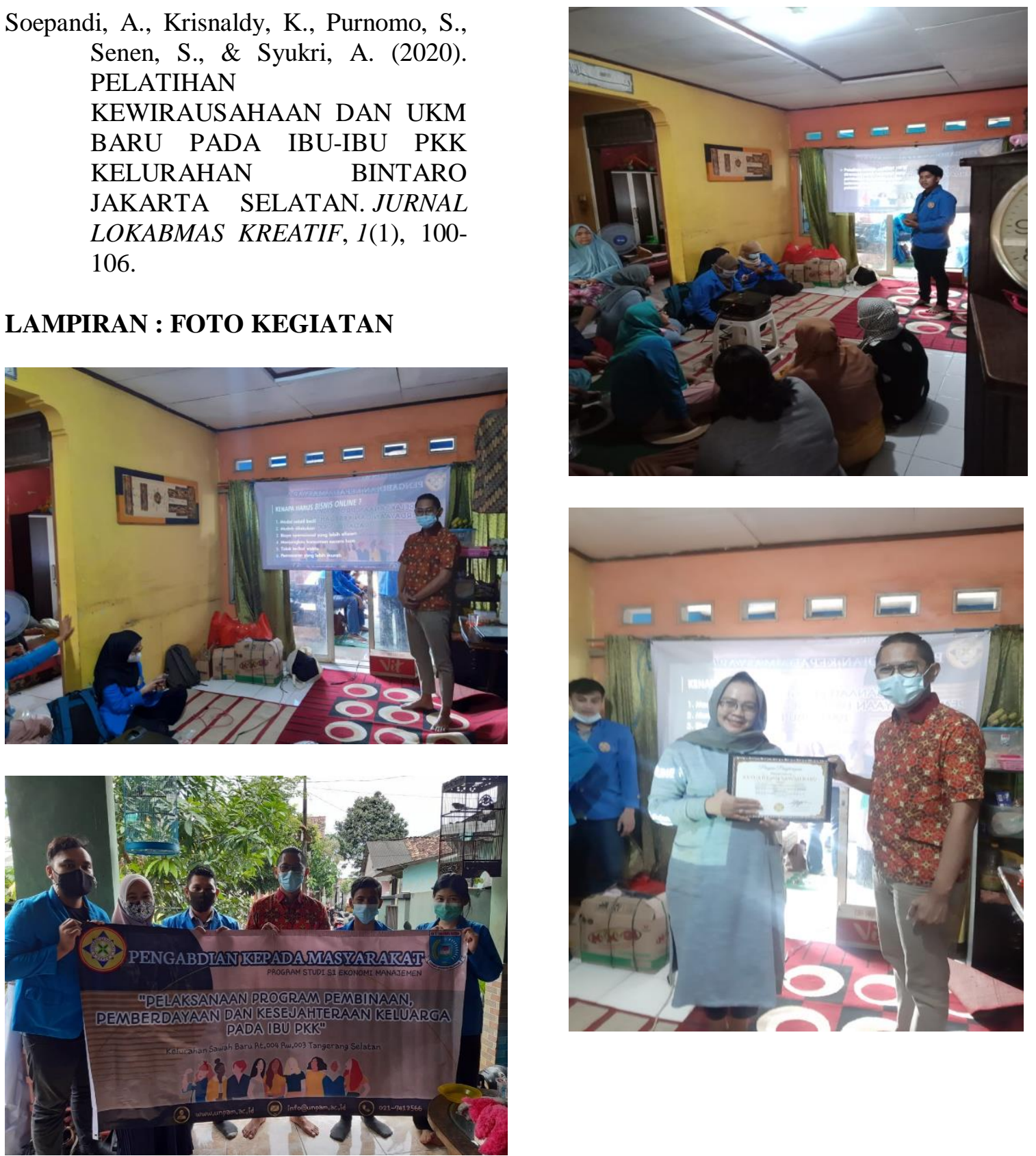